\title{
O COMUNISMO NA HISTÓRIA DO SÉCULO XX
}

Bruno Groppo

As observações que apresentarei a seguir referem-se não à Revolução Russa como um todo, mas ao episódio específico conhecido como Revolução de Outubro, ou seja, a tomada do poder na Rússia em 25 de outubro de 1917 (segundo o calendário juliano então em vigor na Rússia; ou em 7 de novembro, segundo o calendário gregoriano) por parte dos bolcheviques, a ala radical da social-democracia russa. A Revolução de Outubro foi o evento fundador e, ao mesmo tempo, o mito fundador do comunismo do Século $\mathrm{XX}$, na sua dupla dimensão de movimento revolucionário com tendência universalista e de sistema de poder, atuando primeiramente na Rússia e, subseqüentemente, após a Segunda Guerra Mundial, na Europa oriental, na China e em alguns outros países asiáticos, e em Cuba. De um lado, tendo se transformado rapidamente em mito, ela reforçou os fermentos revolucionários já presentes em muitos países; e, de outro, lançou as bases de um novo sistema político e social, o sistema soviético, que perdurou na Rússia por mais de setenta anos e que foi reproduzido nos outros países em

\footnotetext{
* Tradução de Arlete Dialetachi.
} 
que os comunistas ascenderam ao poder. No plano político, a característica fundamental desse sistema era a concentração de todo o poder nas mãos do partido comunista. Na Rússia, os sovietes, que emprestavam seu nome ao sistema e encarnavam, teoricamente, uma forma superior de democracia, se haviam convertido muito rapidamente em uma simples fachada, por trás da qual se encontrava, na realidade, o partido comunista, detentor único do poder.

O comunismo do século XX teve, portanto, desde seu início, uma dimensão dupla; por um lado, de movimento revolucionário; e, por outro, de sistema de poder estatal. Os dois aspectos são indissociáveis. A história do comunismo como movimento revolucionário em escala mundial está estreitamente ligada à história da Rússia e, em seguida, à da União Soviética; e o sistema soviético, na configuração definitiva que lhe foi impressa pelo stalinismo, foi ao longo de muitas décadas o modelo de referência para o conjunto do mundo comunista (formado pelos países, como a China, que em um determinado momento haviam recusado a hegemonia soviética, mas conservado os aspectos essenciais do modelo stalinista). As lutas internas de poder do partido soviético e as decisões políticas tomadas em Moscou haviam exercido uma influência determinante sobre todo o movimento comunista. Na década de 1920, a defesa incondicional da União Soviética se tornou o critério fundamental para a avaliação do caráter revolucionário de um partido comunista. Em outras palavras, o comunismo do século XX se identifica primordialmente com a experiência histórica do poder soviético. Os demais comunismos, heréticos ou dissidentes em relação à ortodoxia stalinista, que também existiram, desempenharam um papel menos importante, freqüentemente marginal.

Na qualidade de evento fundador, a Revolução de Outubro ocupou um lugar central no imaginário político comunista. Todas as correntes e variantes do comunismo 
do século XX - do stalinismo ao trotskismo e ao maoísmo etc. - fizeram referência a ela; e ainda hoje, após o quase desaparecimento do comunismo, continuam a lhe fazer referência os regimes comunistas sobreviventes e os grupos políticos que se declaram ainda comunistas. A Revolução de Outubro foi vista como o anúncio de um mundo novo e de uma nova era, que deveria ter sido a da igualdade, da justiça, do fim da exploração. Na Rússia e na União Soviética, o 7 de novembro tornou-se a principal data do novo calendário político, e como tal era comemorada solenemente todos os anos, até o desaparecimento da União Soviética. A dimensão simbólica e mítica tornou-se rapidamente predominante sobre a realidade do evento. $\mathrm{Na}$ verdade, a "revolução" de 7 de novembro havia sido essencialmente um golpe de Estado executado por uma audaz minoria armada, decidida a tomar o poder à força, e que os bolcheviques conseguiram fazer avalizar no II Congresso Pan-russo dos Sovietes, realizado justamente naqueles dias. A Revolução Russa, que havia posto fim à autocracia czarista, se iniciara em fevereiro de 1917 e se desenvolvera de forma espontânea, sem que nenhum membro dos partidos russos pudesse exercer sobre ela uma influência determinante. No contexto dessa agitação geral, o Outubro bolchevista foi apenas um episódio, que, no entanto, retrospectivamente, aparece como momento culminante, precisamente por ter aberto caminho à instauração de um novo sistema político e social, destinado a perdurar. Nesse sentido, pode-se efetivamente falar da revolução bolchevique como um momento da Revolução Russa. Se os bolcheviques não tivessem conseguido se manter no poder, ela seria certamente recordada de uma forma muito diversa, como um episódio de menor importância.

Como, em sua época, a Revolução Francesa, à qual foi muitas vezes comparada, a Revolução de Outubro também tinha uma predisposição universalista: nas intenções de seus 
protagonistas, particularmente de Lenin, o seu principal artífice, a tomada do poder na Rússia deveria assinalar o início de uma revolução mundial que, da Rússia, teria se estendido à Europa (em primeiro lugar à Alemanha) e depois ao resto do mundo. Os bolcheviques haviam-se convencido de que, se acaso não se estendesse aos demais países, a revolução teria terminado por ser derrotada também na Rússia. As ações deles respondiam, portanto, a uma lógica internacionalista, e foram uma espécie de aposta política que, porém, teve um êxito diferente do previsto, uma vez que a revolução não se estendeu aos demais países mas, nem por isso, foi derrotada na Rússia, e sim conseguiu sobreviver nesse país. Foi nesse cenário imprevisto que os bolcheviques começaram a "construir o socialismo" na atrasada Rússia e que o movimento comunista começou a se estruturar nos outros países.

A predisposição universalista da revolução bolchevique se expressa não apenas na simbologia geral adotada pelo novo regime (a bandeira vermelha como emblema, a Internacional como hino), mas também no próprio nome que foi escolhido, em 1922, para designar a nova entidade política nascida da revolução, ou seja, União das Repúblicas Socialistas Soviéticas. Os dois adjetivos definiam o caráter político da nova entidade, embora o socialismo estivesse ainda por ser construído, enquanto os sovietes correspondiam, sim, à estrutura do novo Estado, mas na realidade já se haviam reduzido a uma mera fachada, por trás da qual se delineava o verdadeiro detentor do poder - o partido comunista. Mas o que realmente impressiona no nome "URSS" é o fato de ele não conter nenhuma indicação geográfica, contrariamente às denominações habitualmente utilizadas para definir as entidades políticas, que fazem referência a um determinado território (República Francesa, Estados Unidos da América etc.). Esse nome designava, portanto, uma entidade política potencialmente universal, capaz de englo- 
bar um número indefinido de outros países (como ocorreu, por exemplo, com os três países bálticos - Estônia, Letônia, Lituânia - em 1940). A adoção da bandeira vermelha como emblema do novo Estado e da Internacional como hino oficial explicitava a ligação com o movimento socialista do século precedente. A URSS pretendia situar-se na tradição do socialismo, ao mesmo tempo que o partido bolchevique rompia com essa tradição de muitas maneiras, inclusive no plano lingüístico, optando, em 1918, por se chamar comunista em vez de social-democrático.

Pensar na tomada do poder na Rússia como o primeiro ato de uma revolução mundial era coerente com a visão internacionalista dos bolcheviques, mas permitia também contornar uma contradição fundamental - o fato de que, segundo os cânones marxistas geralmente aceitos, a Rússia camponesa e subdesenvolvida de 1917 não apresentava nenhuma das condições (um desenvolvimento capitalista avançado, uma classe operária numerosa) consideradas necessárias para a transição para o socialismo. A ausência das condições objetivas era compensada pelo voluntarismo dos bolcheviques [ver Gramsci "Una rivoluzione contro il capitale (Uma revolução contra o Capital) ], determinados a aproveitar uma ocasião histórica única que, provavelmente, jamais voltaria a se apresentar.

No capítulo intitulado "O fascínio universal da Revolução de Outubro”, François Furet observa que:

“a revolução bolchevique de Outubro de 1917 rapidamente adquiriu, nos anos imediatos ao pós-guerra, o status de evento universal. Inscreveu-se na filiação da Revolução Francesa como da mesma natureza, abrindo uma nova era da história da humanidade. Apesar do caráter inverossímil de seu lugar de nascimento, ela realizou um sonho que era inseparável da cultura política européia a partir da Revolução Francesa: o advento de uma sociedade soberana 
de si mesma graças à igualdade finalmente conquistada por seus membros. O privilégio do universalismo bolchevique provém, ao mesmo tempo, da tradição revolucionária da Europa e da situação excepcional do período de 1918 a 1920" (1995, pp. 117-118) ${ }^{1}$.

Os bolcheviques se viram diante da difícil tarefa de "construir o socialismo" em um país em que não existiam as condições preliminares para ele e em que a grande maioria da população, composta de $85 \%$ de camponeses, lhes era hostil. Daí resultou uma forma particular de socialismo, profundamente marcada pela tradição de despotismo própria da Rússia. Um "socialismo" que se havia cristalizado na forma do stalinismo, muito diferente daquele imaginado pela maior parte dos marxistas e dos socialistas do século XIX, em particular no que dizia respeito à sua ligação com a democracia. Esse socialismo, em grande parte improvisado, determinado a prosseguir com as lutas internas pelo poder da elite bolchevique, foi apresentado ao resto do mundo como o socialismo por excelência, que excluía qualquer outro: uma afirmação, que se tornara digna de crédito, de que por trás dessa elite já havia um Estado, a União Soviética.

Teria sido possível percorrer outros caminhos se, quando ficou evidente que a hipótese da revolução mundial não estava mesmo se concretizando, os bolcheviques estivessem

\footnotetext{
1 "Ainsi, la révolution bolchevique d'Octobre 1917 a tout de suite acquis, dans les années de l'immédiat après-guerre, le statut d'un événement universel. Elle s'est inscrite dans la filiation de la Révolution française comme quelque chose du même ordre, ouvrant une époque de l'histoire de l'humanité. Malgré le caractère invraisemblable de son lieu de naissance, elle a comblé une attente inséparable depuis la Révolution française de la culture politique européenne : l'avènement d'une société souveraine sur elle-même par l'égalité enfin conquise de ses associés ». Attente nourrie par l'eschatologie socialiste tout au long du XIXe siècle, et qui a puisé une force renouvelée dans le malheur des (118) peuples pendant la Première Guerre mondiale. Le privilège d'universalisme du bolchevisme provient à la fois de la tradition révolutionnaire de l'Europe et de l'exceptionnelle situation de 1918-1920".
} 
dispostos a renunciar ao monopólio do poder e a buscar um acordo com outras forças políticas. Mas essa possibilidade havia sido categoricamente excluída desde o início, uma vez que os bolcheviques estavam absoluta e fanaticamente convencidos de ser os únicos detentores da verdade. É interessante notar que nem mesmo a oposição trotskista questionava a pretensão do partido comunista de exercitar o monopólio do poder: a idéia de que a classe operária pudesse se exprimir por meio de diferentes partidos políticos constituía também para eles, como para os stalinistas, uma heresia. E não souberam reconhecer que era impossível manter a democracia - no sentido do pluralismo das opiniões - no interior do partido quando ela havia sido destruída no restante da sociedade.

A noventa anos de distância da Revolução de Outubro, o ciclo histórico que ela havia inaugurado parece já concluído. O sistema soviético está extinto e, com ele, desapareceu grande parte do movimento comunista que a ele era organicamente ligado. O império soviético já se desintegrou, e a maioria dos Estados que o integravam se separou dele, recuperando a própria independência. Hoje, o comunismo de modelo soviético que, por decênios, representou uma alternativa concreta ao capitalismo, já não aparece como o protótipo de um futuro desejável também para os outros países, e sim como uma empresa que teve um altíssimo custo humano e que terminou em falência, e que, de uma forma ou de outra, já é um episódio do passado. E justamente por já pertencer ao passado, ele nos permitiu estudá-lo com maior destaque, como parte da história do século XX, e buscar traçar seu balanço. Em retrospectiva, ele foi atingido, acima de tudo, pela força extraordinária do mito da Revolução de Outubro e do eco que ressoou pelo mundo inteiro. Poucos acontecimentos do século XX tiveram uma carga simbólica tão poderosa. Com o Outubro bolchevique nascia uma nova religião política. Muito apro- 
priadamente, Bertrand Russell, em seu Prática e teoria do bolchevismo, publicado em 1920, comparou o comunismo ao islamismo. É igualmente impressionante um segundo aspecto, que é a enorme discrepância, no plano político, entre os objetivos oficialmente proclamados pelos bolcheviques para legitimar sua tomada de poder (isto é, o poder aos sovietes, a democracia direta, o desgaste do Estado etc.) e os resultados efetivamente obtidos na Rússia (um Estado-partido onipresente, um sistema político totalitário, uma nova classe dominante, a perda de toda a autonomia por parte das organizações dos trabalhadores). O contraste entre as promessas e a realidade é evidente desde os primeiros anos do poder soviético. Escreve um historiador inglês:

"Os bolcheviques chegaram ao poder prometendo ao povo, por meio do 'poder dos sovietes', aquilo que o povo desejava mas não conseguira obter do governo provisório: paz, terra, pão, administração dos operários nas fábricas, autodeterminação para a nacionalidade. [...] Eles prometeram paz ao povo, mas o arrojaram em uma nova e terrível guerra civil. Prometeram-lhe pão, mas o fizeram passar tanta fome como já não se via há três séculos. Prometeram-lhe terra, mas o privaram à força dos frutos daquela terra. Prometeram a administração operária, mas agravaram o colapso econômico causando desemprego em massa e quase destruindo a classe operária. Prometeram o poder aos sovietes, mas instauraram a ditadura de um partido único, dispersando a Assembléia Constituinte que poderia ter-lhes sido um obstáculo. Os sovietes demonstraram que eram organismos demasiadamente efêmeros e caóticos para administrar um Estado do século XX, especialmente sob condições tão adversas, e caíram facilmente nas mãos do partido político mais determinado e seguro em si mesmo.” [Hosking, 1998, p. 475] 
O comunismo soviético, portanto, teve resultados contraditórios: transformou radicalmente a face da Rússia, industrializou-a, modernizou-a, fazendo-a sair do atraso e transformando-a em uma superpotência, mas com custos humanos espantosos, suprimindo completamente a democracia e as liberdades públicas, eliminando a autonomia do movimento operário. Quanto ao motivo pelo qual as coisas sucederam dessa forma, as interpretações dos historiadores continuam a divergir. Sem entrar nesse debate, interessanos aqui simplesmente destacar que muitos dos resultados da política bolchevique haviam sido previstos por diversos observadores contemporâneos, particularmente os de orientação socialista. Basta citar, como exemplos, Rosa Luxemburg, Karl Kautsky, Otto Bauer, Bertrand Russell, Julius Martov, Pavel Axelrod, Georgi Plechanov². Muitas dessas análises impressionam por sua precisão em prever certas conseqüências em médio-longo prazo das escolhas que foram feitas, muitas vezes de uma forma totalmente improvisada, pelos bolcheviques no poder. É preciso, porém, constatar que nenhuma delas foi capaz de prejudicar o mito da Revolução de Outubro, provavelmente porque um mito não pode ser destruído com argumentos racionais. A mensagem delas ter-

\footnotetext{
${ }^{2}$ À exceção de Bertrand Russell, os autores citados pertencem todos ao socialismo marxista, e é à luz do marxismo e das controvérsias internas do movimento socialista que eles avaliam a experiência bolchevique. Isso confere freqüentemente a seus textos um caráter de debate quase teológico, com relação à definição do que se deve entender por socialismo e qual seria o caminho mais adequado para chegar até ele. Esse aspecto dos escritos desses autores é certamente o menos válido. Em vez disso, mais interessante é a parte propriamente analítica, na qual eles mostram, por exemplo, como as escolhas dos bolcheviques levaram inevitavelmente à destruição de toda democracia e à instauração de um sistema despótico, em um processo em cujo final o poder teria terminado por se concentrar nas mãos de uma única pessoa. Igualmente notáveis foram as observações deles com relação ao papel desempenhado pela burocracia de partido como nova classe dominante ou à impossibilidade de se preservar a liberdade de discussão e de confronto no interior do partido dominante depois de tê-la destruído na sociedade. Alguns desses temas, como, por exemplo, o da burocracia como classe, seriam mais tarde retomados pelo próprio Trotsky [por exemplo em A revolução traída].
} 
minava, por assim dizer, por se tornar inaudível, diante do fascínio do mito soviético. Observa-se, de resto, que muitas vezes esse fascínio era inversamente proporcional ao grau de conhecimento da verdadeira situação da Rússia soviética. Quanto menos informações sobre a realidade soviética se tivesse, maior a tendência a aceitar, mais com a fé do que com a razão, a imagem oficial proposta pelo poder comunista. Continuava-se, por exemplo, a celebrar os sovietes como uma forma nova e superior de democracia, quando esses estados já se haviam esvaziado de toda substância e sido reduzidos a uma simples aparência, por trás da qual se escondia a ditadura do partido comunista.

$\mathrm{Na}$ maior parte das opiniões e das releituras recentes, a Revolução de Outubro é reconhecida como um evento memorável, uma reviravolta na história do século XX. Ela aparece, entretanto, sob uma luz negativa, como o prenúncio de uma tragédia, a do stalinismo, que seria preferível ter-se evitado. Pesa certamente sobre esse ponto de vista a maneira como a União Soviética e o movimento comunista a ela ligado saíram de cena. É igualmente óbvio que a visão dos historiadores a respeito desse evento continuará a mudar, como aconteceu com a Revolução Francesa. A comparação com a Revolução Francesa põe em evidência uma diferença importante. A um século de distância de 1789, a Revolução Francesa, apesar de continuar a ser objeto de inflamadas controvérsias, era geralmente reconhecida como um evento histórico positivo, portador de valores que permaneciam atuais. A Segunda Internacional, criada em Paris exatamente no primeiro centenário da Revolução Francesa, evoca explicitamente essa tradição revolucionária. Diversa, porém, é a situação, a noventa anos de distância, da revolução bolchevique, que deixou de ser comemorada no país em que ocorreu.

As controvérsias ideológicas que por muito tempo se desenvolveram no socialismo europeu e internacional com 
relação à Revolução de Outubro e à experiência bolchevique, para determinar qual seria o "verdadeiro" socialismo e qual o caminho que se poderia ou deveria percorrer, apresentam hoje um interesse mais histórico que de atualidade política, uma vez que o "modelo" soviético perdeu, antes mesmo de desaparecer juntamente com a falecida União Soviética, a força de atração que tivera em certos períodos. Essas controvérsias agora nos fazem pensar nas disputas teológicas sobre a interpretação das Sagradas Escrituras (sem nos esquecermos de que, em outras épocas, toda disputa teológica tinha sempre enfrentamentos políticos). O leninismo conserva seu fascínio essencialmente como uma tecnologia política para a conquista do poder, como inteligência tática, desprovida de escrúpulos: em outras palavras, como um Maquiavel moderno.

Mais produtiva me parece uma reflexão, com base na experiência histórica da revolução bolchevique e do comunismo, com respeito ao funcionamento dos imaginários políticos: como se formam, de que elementos haurem seu vigor, por que declinam. É importante investigar o mito da Revolução de Outubro e os motivos pelos quais ela teve uma repercussão tão intensa no mundo inteiro e, em particular, no Ocidente. A esse propósito, eu gostaria de citar uma observação, que me parece pertinente, de Marcello Flores. Escreve ele:

"O mito da Revolução Russa - como mais tarde o da URSS e de Stalin - tem suas origens mais nas expectativas internas dos diversos países ocidentais que em uma consciência, por mais aproximada que seja, da realidade soviética. A Revolução de Outubro não poderia ter se tornado um mito se a Europa pós-guerra não se tivesse caracterizado por intensas lutas sociais e violentas batalhas políticas, condições para uma rápida transformação com a qual a Revolução Russa interagiu, influenciando-a mas também sendo por 
ela parcialmente condicionada, alimentando esperanças e receios, aumentando ilusões e temores. A imagem que o Ocidente tinha da revolução era o reflexo das suas expectativas, a percepção de um seu possível futuro, um elemento indispensável da sua identidade, fosse ela desejada ou temida e exorcizada" (Flores, 2007, p. 109).

Não era o conhecimento da realidade soviética que alimentava o mito no Ocidente, mas, ao contrário, a maneira como essa realidade era imaginada e representada fora da Rússia. Na verdade, pode-se afirmar que, quanto mais se conhecia por experiência direta a realidade soviética, menos inclinação se tinha para acreditar cegamente no mito. Além disso, e talvez sobretudo por esse motivo, o regime bolchevique se preocupou, desde o início, em fazer restrições às viagens de delegados ou observadores estrangeiros para a Rússia soviética. Tratava-se de limitar o mais possível o contato direto, sem intermediários, com a realidade soviética, e de mostrar somente aquilo que as autoridades soviéticas julgavam conveniente e em conformidade com a imagem que pretendiam apresentar. A velha prática das "vilas Potiomkin", da época de Catarina II, foi retomada e atualizada pelos bolcheviques no poder. Por outro lado, o fechamento ainda mais hermético das fronteiras, a abolição da figura da oposição, o exílio de todos os partidos políticos com exceção do partido comunista, dificultavam a transmissão de notícias dignas de fé sobre a verdadeira situação da Rússia soviética para o exterior. Isso facilitava a tarefa da propaganda, que se esforçava para transmitir uma imagem idealizada dessa situação.

A noventa anos de distância da tomada do poder por parte dos bolcheviques, o balanço daquela experiência se apresenta repleto de contrastes. Os regimes comunistas, agora poucos, continuam a se recordar daquela experiência, mas o fazem essencialmente para legitimar o mono- 
pólio do poder da elite dirigente. Continuam a existir, em muitos países, grupos que permanecem ligados a essa herança, sobretudo, no caso dos grupos trotskistas, quase sempre muito minoritários. Os partidos comunistas que restam não conseguem se livrar dessa herança, mas dão muitas vezes a impressão de já não saber exatamente o que fazer com ela. Seja como for, esses partidos também já não têm muito peso político. Na Rússia, a postura que prevalece na população e nos meios de comunicação é a de considerar o Outubro bolchevique como o início de uma enorme tragédia, e não, certamente, como um evento a ser celebrado. De forma mais geral, para os movimentos sociais empenhados em vários países nas temáticas ecológicas ou na luta contra a globalização neoliberal, a experiência bolchevique e o leninismo já não representam pontos de referência válidos. $\mathrm{Na}$ Ásia, o Outubro russo provavelmente ainda significa alguma coisa, sobretudo como sinal de um despertar dos movimentos pela independência nacional e contra o imperialismo colonial. O mesmo também deve valer para a América Latina e para a África. Foi sobretudo na Ásia que a mensagem bolchevique teve maior repercussão, sendo interpretada como um instrumento para conquistar a independência diante das potências imperialistas. Seja como for, a impressão global é a de que, como já constatava Enrico Berlinguer muitos anos atrás, a Revolução de Outubro perdeu, e há muito tempo, a sua força propulsora. O modelo econômicopolítico produzido por ela, depois de haver obtido notáveis êxitos industrializando a Rússia (embora com um altíssimo custo humano), acabou por implodir, e já não representa uma alternativa ao capitalismo globalizado.

Chego agora a um ponto que me interessa mais particularmente, que é o tipo de internacionalismo produzido pelo movimento comunista no século XX. Como se pôde notar, já no século XIX o internacionalismo era uma característica fundamental dos movimentos operários emergentes e da 
principal expressão política, o socialismo. Ainda que esses movimentos geralmente se desenvolvessem no âmbito de um quadro nacional, a idéia da necessidade de uma solidariedade internacional dos trabalhadores para se opor a um adversário comum - o sistema capitalista, ele também internacional -, era muito forte. Desde o início, portanto, procurou-se organizar a solidariedade dos trabalhadores não apenas no quadro nacional, mas também no nível internacional. Dessa vontade nasceram as internacionais operárias, fossem políticas ou sindicais. A Primeira Guerra Mundial havia evidenciado os limites desse internacionalismo, que não havia sido capaz de evitar nem a explosão da guerra nem a divisão do movimento operário, com o alinhamento dos partidos socialistas e dos sindicatos dos países envolvidos no conflito sobre os respectivos governos. O fracasso da Segunda Internacional não havia, porém, causado a renúncia à idéia da necessidade de encontrar formas organizacionais adequadas à carência de solidariedade internacional dos trabalhadores. Já durante a guerra se recomeça a tecer os fios do internacionalismo; e depois da guerra esse processo assumirá formas organizacionais e políticas variadas, como a Internacional de Viena, a Internacional Operária Socialista, a Federação Sindical Internacional, a Internacional Comunista.

A Revolução de Outubro abriu caminho para um novo tipo de internacionalismo, que teve sua principal expressão no movimento comunista e que se distingue de todos os outros, precedentes ou contemporâneos, por dois aspectos principais: por um lado, um modo de organização e um funcionamento extremamente centralizados; por outro, a dependência de uma variável externa, o Estado soviético. A novidade se ressalta claramente quando se confronta esse tipo de internacionalismo com as outras formas de internacionalismo desenvolvidas pelo movimento operário antes ou depois de 1917: em nenhuma delas, na verdade, havia existido ou existia um centro único ou um partido-guia ou um Estado-guia. Tanto a 
Primeira quanto a Segunda Internacional eram associações nas quais as organizações filiadas conservavam largas margens de autonomia. Na Segunda Internacional, a social-democracia alemã foi certamente um ponto de referência e, freqüentemente, um modelo para os outros partidos socialistas, mas se tratava de uma influência política, não de uma ligação de tipo organizacional ou de subordinação hierárquica. Após a fratura provocada pela Primeira Guerra Mundial, a Internacional socialista e a Federação Sindical Internacional foram reconstituídas com estruturas de tipo federativo baseadas em ligações flexíveis, que proporcionavam ampla autonomia aos componentes nacionais individuais filiados. Eram essencialmente estruturas de coordenação, não de comando direto.

Com o nascimento do movimento comunista, entretanto, se delineia uma estrutura de tipo novo, fortemente centralizada, copiada do modelo do partido bolchevique. A nova Internacional, amadrinhada pela Rússia bolchevique, foi idealizada como um partido mundial da revolução, cujos partidos comunistas individuais deviam ser simplesmente as seções nacionais, estreitamente subordinadas ao centro. $\mathrm{O}$ modelo era de tipo quase militar, com um enquadramento hierárquico representado por militantes rigorosamente selecionados para se tornarem "revolucionários por profissão”. Foi necessário um certo tempo para que os jovens partidos comunistas se conformassem efetivamente a esse modelo organizacional, calcado sobre o modelo bolchevique. E, na verdade, os anos vinte assistiram a uma sucessão de exclusões e purgações, com as quais foram eliminadas as personalidades excessivamente independentes, pouco inclinadas a aceitar passivamente as determinações de Moscou. Como escreve Marcello Flores:

"Com o Comintern, a uniformidade passaria a ser a regra, e a seleção dos grupos dirigentes seguiria o caminho da cooptação de Moscou, depois de haver marginalizado ou 
expulsado as figuras mais autônomas e originais que haviam surgido em cada país" (Flores, 2007, p114).

Finalmente, o modelo russo se impõe a todo o movimento comunista. No internacionalismo comunista, todos os partidos eram teoricamente iguais. Na prática, porém, se instaurou desde o início uma hierarquia, em cujo vértice se situava o partido comunista russo-soviético. Essa proeminência, inicialmente justificada pelo prestígio que circundava o único partido protagonista de uma revolução vitoriosa, se consolidou rapidamente e continuou a existir mesmo depois da dissolução oficial do Comintern.

A segunda novidade do internacionalismo comunista foi a sua estreita dependência, tanto política como material, de um Estado. Além disso, a União Soviética era um Estado de tipo particular, no sentido de que se tratava de um império, reconstituído com a força dos bolcheviques sobre as ruínas do defunto império czarista. Essa situação, como já dissemos, não tinha precedentes na história do socialismo e do movimento operário: nenhuma das internacionais operárias havia sido a emanação de um Estado, como também não o haviam a Internacional Operária Socialista (IOS) ou a Federação Sindical Internacional (FSI), as concorrentes diretas do Comintern. Tal situação teve um peso determinante sobre toda a história do comunismo no século XX.

A ligação dos partidos comunistas com a URSS nascera da vontade de se solidarizarem com a Revolução de Outubro e com a "pátria do socialismo", sobretudo durante os primeiros anos de existência do novo regime, quando se tratava de defendê-lo contra a intervenção de tropas estrangeiras que apoiavam as armadas brancas. A fidelidade à URSS tornou-se rapidamente o principal elemento constituinte da identidade política comunista, e o fator de identificação do militante comunista. Com a mesma rapidez, a ligação que, de início, fora livremente consentida transformou-se 
em uma relação em que os partidos comunistas dependiam diretamente do Estado soviético, por meio do Comintern. Emerge uma nova lógica pela qual os partidos comunistas "se consideram revolucionários enquanto encararem Moscou como farol e guia" e, em troca, "forem legitimados por Moscou, que controlará seu índice de originalidade e competência revolucionária com base no critério da obediência e da confiança" (Flores, 2007, p. 114).

Para legitimar a dependência dos partidos comunistas em relação à URSS, presumia-se que os interesses do Estado soviético coincidissem sempre e de todas as maneiras com os da revolução mundial. Esse postulado mostrou-se obviamente equivocado, pelo simples motivo de que o Estado soviético, como qualquer outro Estado, tinha seus próprios interesses e agia com base neles, preocupando-se apenas secundariamente com o movimento comunista internacional. Como logo se pôde constatar, os interesses da União Soviética enquanto Estado prevaleceram rapidamente sobre os do movimento revolucionário, e foi a política do Comintern que teve de se adaptar às exigências e às reviravoltas da política soviética, e não vice-versa. (O exemplo mais clamoroso foi o do acordo germano-soviético de 1939, que obrigou todo o movimento comunista a colocar entre parênteses o antifascismo.) A dependência que os partidos comunistas tinham em relação a Moscou tornava simplesmente impensável a hipótese de que eles pudessem definir uma política do movimento comunista diferente da desejada pelo partido russo ou, de qualquer modo, autônoma em relação a ela.

A ligação que se instaurou entre os partidos comunistas e a URSS não era simplesmente de dependência política, mas também de dependência material. Muitos desses partidos recebiam do Estado soviético, de forma direta ou indireta, financiamentos e diversos tipos de ajuda, mais ou menos consistentes, dos quais dependia, em parte, a capacidade deles de desenvolver uma atividade política 
constante. Isso era verdade particularmente para os partidos que desenvolviam suas atividades sob condições de clandestinidade ou de exílio e que, portanto, dispunham de pouquíssimos recursos. Sua capacidade de se manter em operação dependia, em larga medida, da ajuda que a União Soviética lhes podia conceder por meio do Comintern. Essa situação realmente limitava a autonomia dos partidos individuais, ainda que o grau de dependência pudesse variar notavelmente de um partido para outro. A ligação de dependência nos confrontos do Estado soviético não se limitava aos partidos comunistas individuais, mas implicava igualmente o Comintern como tal, pois ele dependia financeiramente de forma quase total do apoio soviético. Desse ponto de vista é interessante o confronto entre o aparato do Comintern e o da Internacional Socialista (IOS) das décadas de 1920 e 1930. O Comintern dispunha, principalmente em Moscou, de um vasto aparato burocrático central, inteiramente financiado pelo Estado soviético. A ele se juntavam suas numerosas ramificações em vários países e nos mais diversos setores: editorial, de cinema, de sociedades comerciais etc., além das numerosas organizações associadas ao Comintern (Profintern, Krestintern, Kim, Socorro Vermelho etc.). Muito diferente era a situação da IOS, que não podia contar com esse tipo de apoio. Seu aparato burocrático era extremamente modesto: limitava-se, na realidade, ao secretário, Fritz Adler, e a seus colaboradores diretos no secretariado da IOS, no máximo umas poucas dezenas de pessoas. As dimensões modestas do secretariado da IOS correspondiam à tarefa que lhe era atribuída, que não era a de dirigir o movimento socialista, e sim a de mediar e de procurar constantemente o denominador comum entre partidos que não pretendiam realmente renunciar à própria autonomia política. Eram os partidos socialistas individuais - ou, no caso da FSI, as centrais sindicais nacionais individuais - 
que tinham um aparato burocrático mais consistente, porque sua área de ação era essencialmente a área nacional. Os militantes ou os dirigentes socialistas tinham um horizonte político primordialmente nacional, ainda que se sentissem solidários com os socialistas dos outros países. Além disso, vale recordar que a IOS era uma organização essencialmente européia, enquanto o Comintern tinha ramificações importantes também em outros continentes.

O comunismo havia introduzido um novo tipo de militância, a do revolucionário por profissão, uma figura que mais raramente se encontrava entre os socialistas da mesma época. Ser revolucionário por profissão significava muito mais: dedicar-se inteiramente à causa comunista, depois de ter sido previamente selecionado para ter acesso a essa elite; viver da política, militando em tempo integral, em troca de uma retribuição geralmente modesta; considerar-se um soldado do exército proletário, disposto a ir aonde quer que o partido o enviasse; pensar em um quadro não somente nacional, e sim mundial. Significava também, em muitos casos, ter passado por adequadas escolas de partido, entre as quais as mais importantes eram as que se situavam na União Soviética, e a primeira dentre todas era a escola leninista de Moscou. Com essa formação, se plasmava um modo de pensar e de agir que caracterizava o quadro comunista independentemente do país de origem. Nem a IOS nem a FSI tinham escolas desse tipo. O Comintern agia também por meio de delegados especiais, encarregados de seguir de perto e de orientar a política de um ou mais partidos comunistas. Sabemos que o papel desempenhado por esses " $m i s s i$ dominici”, verdadeiros e próprios missionários políticos do Comintern, foi muito importante. Impossível de esquecer, igualmente, a rede policial e de espionagem soviética no exterior, em diversos casos utilizada para eliminar fisicamente os comunistas dissidentes, em particular os trotskistas: basta pensar no assassinato de Ignace Reiss, ou no seqüestro 
de Andrès Nin na Espanha, na morte misteriosa de Léon Sedov, filho de Trotsky, e evidentemente no assassinato do próprio Trotsky, ou de ex-dignitários soviéticos que haviam passado para o Ocidente, como Kravitsky.

Entre o aparato do Comintern e o da IOS havia a mesma distância que separa uma multinacional de uma pequena ou média empresa. Encontramo-nos, portanto, diante de duas formas diferentes de internacionalismo, que correspondiam a duas diferentes maneiras de conceber a militância política e, mais em geral, o funcionamento do movimento operário. Cada uma delas apresentava vantagens e inconvenientes. No caso do movimento socialista, o inconveniente consistia na dificuldade de definir e pôr para funcionar uma linha política comum ao conjunto dos partidos, como se pôde constatar sobretudo após a chegada de Hitler ao poder na Alemanha. A vantagem consistia no fato de que cada partido permanecia efetivamente livre de suas escolhas. No caso do Comintern, a vantagem evidente era a maior unidade e, conseqüentemente, a maior eficácia do conjunto, produto de uma disciplina quase militar; a desvantagem consistia na perda de autonomia política dos partidos individuais, e na transposição, em seu interior, dos esquemas autoritários de funcionamento que prevaleciam no partido soviético.

Esses aspectos materiais e organizacionais precisam ser levados em conta porque ajudam a compreender a especificidade do movimento comunista em relação aos seus rivais, tanto os socialistas quanto os comunistas dissidentes. O trotskismo, por exemplo, não pôde jamais contar com o apoio econômico de um Estado, e também por esse motivo, provavelmente, sua influência permaneceu limitada. O próprio Trotsky dependia economicamente de sua atividade de jornalista e escritor.

A dependência dos partidos comunistas em relação à URSS continuou até mesmo depois da dissolução do Comintern, mas de maneiras diferentes, principalmente por meio 
de um relacionamento direto entre o partido soviético e os partidos comunistas individuais. O Cominform, que funcionou de 1947 a 1956 como uma estrutura de coordenação de vários partidos comunistas, não foi uma reedição do Comintern, e sim um organismo muito mais reduzido, uma vez que, além dos partidos comunistas dos países do Leste Europeu que se achavam sob a influência soviética, faziam parte do Cominform somente os partidos comunistas francês e italiano. Como o Comintern, também o Cominform foi essencialmente um instrumento da política exterior soviética, e situa-se no quadro da nova configuração geopolítica do comunismo que emergiu como resultado da Segunda Guerra Mundial - a formação de um, por assim dizer, "campo socialista" que abrangia a Europa Oriental, e depois a China, a Coréia do Norte e o Vietnã do Norte. Quando, mais tarde, ocorreu o cisma chinês, se instaurou um relacionamento de dependência semelhante entre o Estado chinês e os partidos maoístas que se formaram em vários países: reproduzia-se, nesse caso, o mesmo modelo instaurado pela União Soviética.

A dependência financeira dos partidos comunistas em relação à URSS podia se apresentar sob várias formas: financiamentos diretos ou indiretos, formação na URSS de quadros de funcionários desses partidos, férias e residência gratuitas na URSS de dirigentes comunistas estrangeiros, fornecimento de armas, publicações impressas diretamente na URSS etc. Isso não significa que os partidos comunistas fossem criações artificiais, incapazes de existir sem a ajuda soviética. Enquanto respondessem efetivamente às verdadeiras necessidades e às aspirações de uma parte dos trabalhadores de um país, eles podiam se radicar ali e encontrar nesse próprio país os recursos necessários para sua atividade política. A ajuda por parte da URSS, ou de outros países comunistas, era, porém, crucial para os partidos comunistas reduzidos à clandestinidade e ao exílio. 
Quando se fala da ligação de dependência com o Estado soviético, não se deve esquecer de que a URSS era na realidade um império, em cujo interior o componente principal, a Rússia, era ela própria um Estado multinacional. O império czarista, que se havia desintegrado em conseqüência da guerra e da revolução, havia sido em grande parte reconstituído, na verdade, sob a autoridade dos bolcheviques. As referências e os símbolos políticos haviam mudado, mas a política do império soviético se situava, em certos aspectos, na continuidade da política do império czarista (por exemplo, nos confrontos dos países bálticos ou da Polônia). O fim da URSS foi também o fim de um império, e apresenta analogias com o fim do império czarista no contexto da revolução russa de 1917 (por exemplo, a independência dos países bálticos, da Geórgia etc.). Em teoria, a URSS podia ser o protótipo de uma comunidade internacional comunista estabelecida sobre a livre associação de estados, no que dizia respeito à autonomia de qualquer um deles. A realidade, entretanto, era um pouco diferente: baseava-se nos relacionamentos de força no interior de uma estrutura imperial, em que a vontade do centro prevalecia sempre sobre a da periferia. Os interesses da União Soviética na condição de império pesavam fortemente sobre as orientações do movimento comunista.

Depois da Segunda Guerra Mundial, e como resultado dela, o comunismo apresenta uma configuração nova, muito diferente da que tinha antes da guerra. Graças à expansão territorial na Europa e depois na Ásia, o comunismo se apresenta agora como um sistema de estados, em cujo centro se encontra a União Soviética, que se tornara uma das duas superpotências mundiais. Da outra vertente, a do comunismo como movimento, os partidos comunistas em geral saíram reforçados da guerra mundial, graças sobretudo ao papel por eles desempenhado na resistência à ocupação nazista, e graças ao prestígio da União Soviéti- 
ca vitoriosa. Particularmente importante é a expansão da influência comunista na Ásia, em que os partidos comunistas são, muitas vezes, o principal componente das formações políticas que lutam pela independência nacional contra o colonialismo.

Como sistema de estados, o internacionalismo comunista reproduz o mesmo tipo de relacionamento que havia existido no interior do Comintern entre o Partido Comunista da União Soviética e os outros partidos comunistas. A URSS impõe aos novos estados comunistas uma rígida subordinação a seus próprios interesses e sufoca todas as tentativas de autonomia. Quando um Estado comunista reivindica sua autonomia, aproxima-se rapidamente do conflito e da ruptura, como aconteceu primeiro com a Iugoslávia de Tito e depois com a China de Mao. Se nesses dois casos a URSS não conseguiu se impor, em outros as tentativas de conquista de autonomia ou de independência empreendidas pelas elites comunistas locais foram reprimidas sem hesitação pelas forças militares da URSS, como ocorreu em 1956 na Hungria e em 1968 na Tchecoslováquia.

O resultado desse tipo de relacionamento e dessas políticas é que, nos países europeus compreendidos na esfera de domínio soviética, o comunismo é geralmente considerado pela maioria da população como um regime imposto de fora e desprovido de legitimidade própria. Por esse motivo, quando se relaxa o aperto soviético em torno desses países, os regimes comunistas, já não podendo contar com o apoio soviético, caem um após o outro, em rápida sucessão.

Para os partidos comunistas que não se encontram no poder, o internacionalismo continua a ser visto como uma forte ligação com a União Soviética, mas a legitimidade desta última se encontra profundamente prejudicada pela denúncia dos crimes de Stalin no XX Congresso do Partido Comunista da União Soviética, pela ruptura com a China e pela sucessão de crises graves na Europa Oriental (Hungria, 
Tchecoslováquia, Polônia). A Revolução de Outubro continua a ser um ponto de referência fundamental para os partidos comunistas, mas a ligação com a URSS começa a ser vista mais como um obstáculo do que como um benefício. Na Europa Ocidental, muitos partidos comunistas se esforçam para se livrar dessa ligação, e alguns já não hesitam em questionar até mesmo os mitos fundadores. O PCI de Berlinguer, por exemplo, não hesitará em declarar que a força propulsora da Revolução de Outubro já se havia esgotado.

Do tipo de internacionalismo para o qual a Revolução de Outubro havia aberto o caminho, resta hoje muito pouco. Em níveis oficiais, nenhum dos países que permaneceram comunistas aspira a coordenar e dirigir um movimento comunista mundial, e o antigo modelo soviético-stalinista do socialismo de Estado já não parece hoje possível de ser proposto. Os demais partidos comunistas que não se encontram no poder vivem, ou sobrevivem, cada um por sua própria conta, sem que entre eles exista alguma forma de coordenação. A tentativa mais interessante de coordenação regional foi, nos anos 1970, a eurocomunista, que, porém, se limitava apenas a alguns partidos e funcionou somente por um período limitado de tempo.

Após o desaparecimento da União Soviética, não surgiu nenhuma instância suscetível de se tornar um ponto de referência e um denominador comum para os partidos e os grupos herdeiros do comunismo ortodoxo. Na América Latina, Cuba tentou desempenhar esse papel, mas ela também está às voltas com os seus próprios problemas, antes de qualquer outro o da sucessão de Castro, que se encontra no poder já há quase meio século.

Em conclusão, o fascínio do Outubro russo, que no seu tempo contribuiu intensamente para a difusão do movimento comunista no mundo, pertence já ao passado. Os movimentos sociais e políticos hoje empenhados na luta contra a globalização neoliberal não fazem referência, sal- 
vo algumas exceções, à Revolução de Outubro e ao modelo político que dela surgiu. As alternativas ao capitalismo são procuradas em outras direções, também porque o modelo soviético-stalinista chegou ao fim com um evidente fracasso e já não parece uma alternativa realista.

O comunismo do século XX foi um fenômeno transnacional tanto do ponto de vista político como no plano cultural. Produziu uma cultura política que deitou raízes em países e ambientes profundamente diferentes, da China ao Chile, do México ao Japão. É importante, a esse respeito, refletir sobre sua relação com o Ocidente e, em particular, com a Europa. O comunismo nasceu em um país agrário, semi-europeu e semi-asiático, onde apenas recentemente se havia iniciado um vigoroso processo de industrialização. Um dos motivos de seu sucesso no plano internacional foi a sua luta contra as formas de dominação colonial ainda prevalecentes na Ásia e na África. O comunismo pareceu encarnar a vontade e a exigência de pôr fim a esse tipo de dominação, e era, portanto, de se esperar que encontrasse um eco favorável nesses países: o comunismo foi, com freqüência, o instrumento utilizado pelas elites modernizadoras desses países para conquistar a independência. $\mathrm{O}$ exemplo soviético de industrialização de um país agrário atrasado aparecia ainda como um modelo para países que tentavam sair do subdesenvolvimento e da dependência. A estratégia do Comintern, entretanto, permaneceu centralizada essencialmente sobre a Europa.

\section{Conclusão}

Hoje, a noventa anos de distância desses acontecimentos, o aniversário da Revolução de Outubro é celebrado oficialmente apenas nos raros países sobreviventes do mundo comunista do passado, em grande parte já desaparecido. $\mathrm{Na}$ Rússia, ou nos países em que se produziu o evento fundador e onde foi "inventada" essa tradição, esse aniversário deixou 
de ser celebrado desde quando a União Soviética deixou de existir. O 7 de Novembro não é mais feriado nacional, mas foi rebatizado "Dia da Reconciliação" (День примирения). Em seu lugar foram introduzidas festas de caráter nacional, como a Festa da Unidade Nacional (4 de novembro) ou o Dia da Rússia (Festa Nacional da Independência em 12 de junho, que recorda a primeira eleição presidencial com voto universal, introduzida após a Declaração de Soberania da Rússia). A Rússia pós-comunista quis romper deliberadamente com a memória da Revolução de Outubro e busca em outros momentos de seu passado os pontos de referência adequados para redefinir sua própria identidade. Um dos mais importantes é ainda o que diz respeito à Segunda Guerra Mundial (que na Rússia é chamada de "a grande guerra patriótica”). Nos demais países ex-comunistas também se parou de comemorar oficialmente o 7 de Novembro, símbolo de um passado comunista de conotação negativa e com o qual se deseja romper definitivamente. Nos raros países ainda sob o sistema comunista, a comemoração ainda tem lugar, mas se trata de uma cerimônia ritual de legitimação política, que já não encarna a promessa de um futuro radicalmente diferente. A crença em uma revolução mundial, mais ou menos próxima, desapareceu. A Revolução de Outubro permanece como um ponto de referência importante para os países comunistas que ainda existem, mas cujo declínio não parece destinado a cessar, e para uma miríade de grupos - dos trotskistas aos maoístas, passando por diversas formas de neo-stalinismo - que continuam a se definir como comunistas. Basta navegar, mesmo que rapidamente, pela internet, para constatar que a Revolução de Outubro ainda tem entusiásticos admiradores por todo o mundo, mas fica também evidente que essa nebulosa, em grande parte formada por grupos pequenos e pouco influentes, não é um ator político nem mesmo de longe comparável ao movimento comunista internacional de outros tempos. 
Na vertente hostil ao comunismo, o Outubro bolchevique torna-se objeto de um julgamento em plena vigência, muitas vezes estendido ao conjunto do socialismo, ao marxismo e à própria idéia de revolução.

$\mathrm{Na}$ maior parte das opiniões e releituras recentes, a Revolução de Outubro é, porém, reconhecida como um evento de época, como uma reviravolta na história do século $\mathrm{XX}$; mas aparece preponderantemente sob uma luz negativa, como o prenúncio de uma tragédia e de um fracasso de dimensões inimagináveis. Pesa certamente sobre essa visão o modo como a União Soviética e o movimento comunista por ela legado saíram de cena.

\section{Bruno Groppo}

é professor da Université Paris I - Sorbonne, onde atua no Centre de Recherche d'Histoire des Mouvements Sociaux et du Syndicalisme; é pesquisador do Centre D'Histoire Sociale de XXe Siècle, no Centre National de la Recherche Scientifique (CNRS)

\section{Bibliografia}

FLORES, M. 2007. 1917. La rivoluzione. Torino: Einaudi.

FURET, F. 1995. Le passé d'une illusion. Essai sur l'idée comunist au XX $\mathrm{X}^{\mathrm{e}}$ siecle. Paris: Robert Laffont, Calamann-Lévy.

HOSKING, G. 1998. Russia: People and Empire, 1552-1917 (Rússia: Povo e Império, 1552-1917). Cambridge, Mass.: Harvard University Press.

RUSSELL, B. 1920. The practice and theory of bolshevism. London: George Allen \& Unwin. 


\section{O COMUNISMO NA HISTÓRIA DO SÉCULO XX}

BRUNO GROPPO

O comunismo do século XX teve, desde seu início, uma dimensão dupla: o movimento revolucionário, por um lado; o sistema de poder estatal, por outro. Os dois aspectos são indissociáveis. A história do comunismo como movimento revolucionário em escala mundial está estreitamente ligada à história da Rússia e, em seguida, à da União Soviética. E o sistema soviético, na configuração definitiva que lhe foi impressa pelo stalinismo, foi ao longo de muitas décadas o modelo de referência para o conjunto do mundo comunista. Em outras palavras, o comunismo do século XX identifica-se primordialmente com a experiência histórica do poder soviético. Os demais comunismos, heréticos ou dissidentes em relação à ortodoxia stalinista, desempenharam um papel menos importante, freqüentemente marginal.

Palavras-chave: Comunismo do século XX; Modelo soviético; Movimento revolucionário comunista; Estado soviético.

\section{COMIMUNISM IN THE TWENTIETH-CENTURY HISTORY}

Twentieth-century communism had, since the beginning, a double dimension: the revolutionary movement, on the one hand; the state power system, on the other. Both sides are inseparable. The history of communism as a revolutionary movement in world scale is intimately linked to the Russian and then Soviet history. And the Soviet system, in the final configuration stalinism gave to it, was a model to the whole communist world along many decades. So that twentieth-century communism is primordially identical with the historical experience of the Soviet power. Other brands of communism, heretical or dissident to Stalinist ortodoxy, performed a less important, often marginal, role. 
Keywords: Twentieth-century communism; The Soviet model; The communist revolutionary movement; The Soviet State. 